\title{
CROPS AND SOILS RESEARCH PAPER Screening of plant extracts for antifungal activities against Colletotrichum species of common bean (Phaseolus vulgaris L.) and cowpea (Vigna unguiculata (L.) Walp)
}

\author{
J. I. G. MASANGWA ${ }^{1}$, T. A. S. AVELING ${ }^{1}$ AND Q. KRITZINGER \\ ${ }^{1}$ Department of Microbiology and Plant Pathology, Forestry and Agricultural Biotechnology Institute, University of Pretoria, \\ Pretoria 0002, South Africa \\ ${ }^{2}$ Department of Plant Science, University of Pretoria, Pretoria 0002, South Africa
}

(Received 6 October 2011; revised 27 March 2012; accepted 2 May 2012)

\section{SUMMARY}

The aim of the present investigation was to evaluate the antifungal activities of plant extracts which can be used to control bean and cowpea anthracnose. Acetone, ethyl acetate and water extracts of Ipomoea batatas, Carica papaya, Allium sativum, Syzygium cordatum, Chlorophytum comosum and Agapanthus caulescens were screened in vitro for their antifungal activities against Colletotrichum lindemuthianum and Colletotrichum dematium of common bean and cowpea using the agar disc infusion and microtitre double-dilution techniques. The same extracts were then tested for antifungal activity in vivo as seed treatments against anthracnose disease. The water extracts of Carica and Syzygium were active against $C$. lindemuthianum and had minimum inhibitory concentrations (MICs) of $1.56 \mathrm{mg} / \mathrm{ml}$. Syzygium, Allium and Chlorophytum water extracts were active against C. dematium and MICs were $3 \cdot 13,6.25$ and $12.5 \mathrm{mg} / \mathrm{ml}$, respectively. The MICs of Allium, Syzygium and Agapanthus acetone extracts were $0 \cdot 78,3.13$ and $6.25 \mathrm{mg} / \mathrm{ml}$, respectively, against $C$. lindemuthianum and $0 \cdot 78$, 6.25 and $3.13 \mathrm{mg} / \mathrm{ml}$ against $C$. dematium. Agapanthus water extracts and all the acetone extracts tested in vivo effectively reduced the incidence and severity of bean anthracnose disease in the greenhouse. Agapanthus acetone, Allium water, and both acetone and water extracts of Carica and Syzygium performed well in vivo in reducing cowpea anthracnose disease and compared well with reductions due to the application of the synthetic fungicide fludioxonil + mefenoxam (the commercial product Celest ${ }^{\circledR} \mathrm{XL}$ ) applied at 25 gai/l and also with levels in the non-inoculated control. The Agapanthus, Carica, Syzygium and Allium extracts were active on both Colletotrichum spp. in vitro and also reduced anthracnose disease of bean and cowpea and are potential seed treatments in anthracnose disease control. The easy seed treatment process and the accessibility of plants used in the present study could lead to high adoption of the use of the plant extracts as seed treatments by resource-poor, smallholder farmers.

\section{INTRODUCTION}

Common bean (Phaseolus vulgaris L.) and cowpea (Vigna unguiculata (L.) Walp) are two important legume crops that are commonly grown in subSaharan Africa for food, cash, animal feed and as soil improvers. The seeds of the two crops are a cheap source of protein for the people of this region and ease of storage leads to their preference over meat products by smallholder farmers (Msuku et al. 2000), who

* To whom all correspondence should be addressed. Email: Terry. aveling@fabi.up.ac.za mostly lack cooling facilities. It has been reported that the two crops also have medicinal properties (Kritzinger et al. 2005; Wong et al. 2006; Jeng et al. 2009). Leaf extracts of cowpea (Kritzinger et al. 2005) and seed extracts of both crops have antifungal activities against some phytopathogens (Ng 2004), making them a potential source of agricultural fungicides.

Despite the importance of the two crops, farmers fail to realize maximum potential yields because of several limiting factors, among them the incidence and severity of diseases (Beaver et al. 2003; 
Adebanjo \& Bankole 2004). Anthracnose is a common disease of legumes and is caused by Colletotrichum spp. Common bean anthracnose is caused by Colletotrichum lindemuthianum (Sacc. and Magn.) Bri. and Cav., whereas cowpea anthracnose is initiated by both Colletotrichum dematium (Fr.) Grove var. truncata and C. lindemuthianum. Anthracnose is a seed-borne disease and complete crop failure can be expected under heavy infection (Allen 1983; PastorCorrales \& Tu 1989). The pathogen has also been reported to be associated with humans and animals, making its control imperative (Cano et al. 2004; Mendiratta et al. 2005). For example, C. dematium has been implicated in corneal ulcers in humans (Mendiratta et al. 2005).

The current major means of controlling anthracnose is the use of synthetic fungicides (Tian et al. 2007) through seed dressing and foliar application. However, several problems pertaining to the use of synthetic fungicides have been reported, including accumulation of harmful chemical residues in seeds, water and soil and also the induction of resistance in the pathogens (Falandysz 2000; Shovan et al. 2008). Therefore, there is a need for safer alternative fungicides.

A survey by Mwine et al. (2011) in the Masaka district, southern Uganda, reported that 34 plant species belonging to 18 families were used in traditional plant production for plant protection by smallholder farmers. Among these were Allium sativum (garlic) water extracts, used against field and storage pests, and Carica papaya (pawpaw) water extracts, used against 'blight'. In a survey involving smallholder farmers in Zimbabwe, Sibanda et al. (2000) found that many of the farmers had tried or heard about spraying with botanical extracts from plants such as Mexican Marigold (Tagetes spp.), garlic, chillies (Capsicum frutescens L.) and tobacco (Nicotiana tabacum L. and other spp.) against pathogens and pests. The present authors were unable to find any reported surveys on the use of plant extracts as seed treatments by smallholder farmers.

There are many plants that are toxic to Colletotrichum; however, research in this field has focused upon the anthracnose diseases of other vegetables and fruits (Raghavendra et al. 2006; Chowdhury et al. 2007; Nduagu et al. 2008; Mdee et al. 2009) and little has been done on the anthracnose of beans and cowpea (Amadioha 2003; Shovan et al. 2008; Akinbode \& Ikotun 2008). There is a need to search for plants that have fungicidal properties against
Colletotrichum on legumes. The plant species A. sativum, Agapanthus, Syzygium, C. papaya, Chlorophytum and Ipomoea batatas have been reported to possess antifungal properties against other phytopathogens (Pretorius et al. 2002; Taiga et al. 2008; Tegegne et al. 2008).

The present work therefore aimed to (1) evaluate plant extracts for their antifungal activities against C. dematium and C. lindemuthianum that could possibly lead to their use for the control of cowpea and bean anthracnose, (2) determine the minimum inhibitory concentrations (MICs) of different plant extracts extracted by different solvents and (3) evaluate the performance of some extracts as cowpea and bean seed treatments against $C$. dematium and $C$. lindemuthianum, respectively, in vivo in the greenhouse.

\section{MATERIALS AND METHODS}

\section{Plant material}

The plant materials used in the present study were Syzygium cordatum Hochst.ex Krauss. (fruits from a tree in the family Myrtaceae), Chlorophytum comosum (Thunb.) Jacq. cvar variegatum (whole plant, spider plant, herbaceous, family Asparagaceae), Agapanthus caulescens Spreng. (whole plant, herbaceous, family Amaryllidaceae), I. batatas (L.) Lam. (leaves, sweet potato, family Convolvulaceae), A. sativum L. (bulbs, garlic, family Amaryllidaceae) and C. papaya L. (leaves, pawpaw, family Caricaceae). Collections of $S$. cordatum, C. comosum and A. caulescens were made from the Manie van der Schijff Botanical Garden at the University of Pretoria, Pretoria, Republic of South Africa (RSA). The sweet potato leaves were collected from the University of Pretoria's Experimental Farm, whereas the garlic bulbs were bought at the Pretoria fresh market and the pawpaw leaves were collected from Durban in Kwazulu-Natal province, RSA. Samples of the collected plants were deposited in the University of Pretoria H.G.W.J. Schweickerdt Herbarium and voucher numbers were assigned (Table 1).

Preparation of the crude plant extracts

All the plant materials were air dried in the shade and ground to powder using a pestle and mortar. Sequential extractions were performed on $1 \mathrm{~kg}$ of each plant powder by soaking them in 2 litres of 27.06 moles acetone, 20.30 moles ethyl acetate and 
Table 1. The quantities ( $g$ ) of crude extracts harvested from $1 \mathrm{~kg}$ plant material using acetone, ethyl acetate and water as solvents

\begin{tabular}{lllrr}
\hline \hline & & & \multicolumn{2}{c}{ Solvent } \\
\cline { 3 - 5 } Plant name & Voucher no.* & Acetone & Ethyl acetate & Water \\
\hline Agapanthus caulescens & PRU96528 & 7 & 13 & 53 \\
Allium sativum & PRU96551 & 14 & 4 & 414 \\
Carica papaya & PRU96552 & 33 & 15 & 103 \\
Chlorophytum comosum & PRU96518 & nd & nd & nd \\
Ipomoea batatas & PRU96529 & nd & nd & nd \\
Syzygium cordatum & PRU96517 & 20 & 18 & 125 \\
\hline \hline
\end{tabular}

* Voucher number assigned by the University of Pretoria H.G.W.J. Schweickerdt Herbarium.

nd, not determined.

sterile distilled water ( $24 \mathrm{~h}$ in each). The plants were soaked in that order contingent to the polarity of the solvents. The organic solvents were removed using a Büchi Rotavapor (Model R-200, Switzerland) and water plant filtrates were concentrated to powder using a freeze drier (Edwards High Vacuum International, Sussex, England). Different quantities of crude extracts were harvested from different solvents as shown in Table 1. All the extracts were then stored in the fridge at $4{ }^{\circ} \mathrm{C}$.

Collection of anthracnose infected plants and isolation of Collectotrichum spp.

Anthracnose-infected common bean and cowpea plants were collected from Middelburg $\left(25^{\circ} 39^{\prime} \mathrm{S}\right.$ and $029^{\circ} 45^{\prime} \mathrm{E}$ ), Mpumalanga province, RSA and the Department of Agriculture experimental farm $\left(25^{\circ} 46^{\prime} \mathrm{S}\right.$ and $\left.31^{\circ} 1^{\prime} \mathrm{E}\right)$, Nelspruit, Mpumalanga, RSA, respectively. Stems and leaves were surface disinfected in $0.15 \mathrm{mg} / \mathrm{ml}$ sodium hypochlorite for $3 \mathrm{~min}$ and rinsed three times in sterile distilled water, and then placed either on moist blotters in Petri dishes or on potato dextrose agar (PDA) under continuous ultraviolet light for 7 days at $24 \pm 2{ }^{\circ} \mathrm{C}$. Colletotrichum spp. were morphologically identified using the Common Laboratory Seed Health Testing Methods for Detecting Fungi (Mathur \& Kongsdal 2003) and were subcultured and stored in a fridge $\left(4^{\circ} \mathrm{C}\right)$ until needed.

\section{Antifungal bioassays}

Agar infusion assay

The antifungal activity of the extracts was determined by adopting the technique described by Kritzinger et al. (2005) where appropriate amounts of each stock of crude extract was added to $100 \mathrm{ml}$ of PDA before pouring into Petri dishes to yield final concentrations of $0 \cdot 5,1 \cdot 0,2 \cdot 5$ and $5 \cdot 0 \mathrm{mg} / \mathrm{ml}$. The amended PDA was poured into $65 \mathrm{~mm}$ Petri dishes with preset diametrical lines drawn on the bottom plate to identify the centre of the plate. Plugs ( $5 \mathrm{ml}$ diameter) of $C$. lindemunthianum and $C$. dematium from 7-day-old fungal cultures were placed in the centre of the Petri dishes containing PDA amended with either water extracts, acetone extracts $0.05 \mathrm{ml} / \mathrm{ml}(\mathrm{v} / \mathrm{v})$, ethyl acetate extracts $0.05 \mathrm{ml} / \mathrm{ml}(\mathrm{v} / \mathrm{v})$, the fungicide fludioxonil + mefenoxam (as commercial product Celest ${ }^{\circledR}$ XL (25 gai/l) Syngenta SA, Midrand). The Petri dishes were then sealed with Parafilm ${ }^{\circledR}$ and incubated at $25^{\circ} \mathrm{C}$. Acetone, ethyl acetate and unamended PDA represented the negative controls. Celest ${ }^{\mathbb{B}} \mathrm{XL}$ represented the positive control based on previous work (Aveling et al. 2012). The treatments were arranged in a completely randomized design and each treatment was replicated four times. The experiment was repeated twice. Evaluation of Petri dishes was executed by measuring the diameter of growth inhibition zones after 3, 6 and 9 days of incubation (DAI). The formula of Tegegne et al. (2008) was used to calculate the proportional inhibition of mycelial growth:

Inhibition $=\frac{\mathrm{d} c-\mathrm{d} t}{\mathrm{~d} c}$

where $d c$ is the average diameter of fungal colony of the negative control (PDA only) and $\mathrm{d} t$ is the average diameter of fungal colonies grown in the presence of plant extracts or standard fungicides.

The inhibition data were arc sine transformed and then analysed statistically using the Genstat computer package (VSN International 2008). The untransformed 
and transformed data led to the same conclusion, hence the untransformed analysis data have been presented.

\section{Microtitre double-dilution assay}

Malt extract broth was inoculated with Colletotrichum fungi and incubated for 5 days at $25^{\circ} \mathrm{C}$. The broth was adjusted to $0 \cdot 2$ optical density (thus $1 \times 10^{5}$ and $1 \times 10^{6} \mathrm{spores} / \mathrm{ml}$ for C. lindemuthianum and C. dematium, respectively) using an electrospectrometer just before inoculation.

In order to yield a series of $50 \mathrm{mg} / \mathrm{ml}$ solutions of extracts, $50 \mathrm{mg}$ of each of the plant extracts were dissolved in $1000 \mu \mathrm{l}$ of $121.7 \mathrm{mg} / \mathrm{ml}$ dimethyl sulphoxide (DMSO). The 96-well microtitre plates were used and $100 \mu$ of the broth was added to all the wells as follows: $100 \mu \mathrm{l}$ of stock solution $(50 \mathrm{mg} / \mathrm{ml})$ of acetone plant extracts were added to the first three wells of row $A$, ethyl acetate plant extracts were added to the wells 4-6 and water plant extracts were added to wells 7-9. Nutrient broth was added to well 10 as a negative (sterility) control, while Celest ${ }^{\circledR}$ XL $(100 \mu \mathrm{l}$ of $2.5 \mathrm{ml} / \mathrm{ml}(\mathrm{v} / \mathrm{v}))$ was added to well 11 as a positive control. To well $12,100 \mu \mathrm{l}$ of $121.7 \mathrm{mg} / \mathrm{ml}$ DMSO was added as a negative control. A series of dilutions of plant extracts, Celest ${ }^{\circledR} \mathrm{XL}$ and $121.7 \mathrm{mg} / \mathrm{ml}$ DMSO were carried out to row $\mathrm{H}$.

Six-day-old malt broth cultures $(100 \mu \mathrm{l})$ of Colletotrichum fungi were added to each well. The plates were divided into two sets; the first set (six plates) was inoculated with $C$. lindemuthianum and the other with $C$. dematium. The plates were then covered with lids, sealed with Parafilm ${ }^{\circledR}$ and incubated at $25^{\circ} \mathrm{C}$ for $48 \mathrm{~h}$. Thereafter, $40 \mu \mathrm{l}$ of $0.2 \mathrm{mg} / \mathrm{ml}$ iodonitrotetrazolium (INT) chloride was added to all the wells, with the exception of columns 3, 6 and 9 as a growth indicator to determine the MIC values for the 18 plant extracts. The microtitre plates were incubated for $24 \mathrm{~h}$ at $25{ }^{\circ} \mathrm{C}$ and evaluated. The first clear wells from $\mathrm{A}$ to $\mathrm{H}$ were regarded as the MICs of extracts. The experiment was repeated three times and the final MIC for the extracts was calculated as described by Fawole et al. (2009).

\section{In vivo antifungal test}

The varieties used in the present study were the common bean variety Jenny, and IT93K5132 (cream coloured) and Pan 311 (brown coloured) cowpea varieties. Bean and cowpea seeds were soaked in sterile distilled water for $30 \mathrm{~min}$. A small hole of $3 \mathrm{~mm}$ was made on each seed into the cotyledon using a sterile needle. The pricked seeds were then soaked in $1 \times 10^{6}$ Colletotrichum spore concentration made from a 10-day-old culture to which 20 drops of Tween 20 was added to yield $0.075 \mathrm{mg} / \mathrm{ml}$ Tween 20 solution. Bean and cowpea seed were soaked in C. lindemuthianum and $C$. dematium, respectively, for $4 \mathrm{~h}$ in the dark. The suspension was drained after $2 \mathrm{~h}$ and the seeds were placed under high humidity conditions by placing them between moist sterile paper towels in a tightly sealed container overnight, to allow fungal infection to take place. The seeds were then soaked in $150 \mathrm{ml}$ of selected plant extracts diluted to 5 and $15 \mathrm{mg} / \mathrm{ml}$ for $24 \mathrm{~h}$ at $25^{\circ} \mathrm{C}$ and kept in the dark. The inoculated seeds soaked in Celest ${ }^{\circledR} \mathrm{XL}$ (25 gai/l) and non-inoculated seeds soaked in distilled water served as positive controls. The negative controls comprised inoculated seeds soaked in distilled water and $121.7 \mathrm{mg} / \mathrm{ml} \mathrm{DSMO}$, respectively. The seeds were then sown in pots 150 (diameter) $\times 125 \mathrm{~mm}$ (depth) filled with a steam-sterilized mixture of sand and garden compost (Culterra (Pty) Ltd, Pretoria) in a ratio of $1: 1(\mathrm{~m} / \mathrm{m})$ at the rate of six seeds per pot. Each treatment was replicated four times and treatments were arranged in a randomized complete design. Water was applied daily in order to maintain soil moisture at field capacity. Each experiment was repeated twice. Data collected included anthracnose disease incidence and severity. The disease incidence was calculated by the formula below:

Disease incidence $=\frac{\text { No. of infected plants per pot }}{\text { No. of plants per pot }}$

The anthracnose disease severity scale of 1-9 (CIAT 1987) was employed during the disease severity data collection. Arc sine transformation was performed on anthracnose disease severity data before statistical analysis. The Genstat Discovery statistical package (VSN International 2008) was used to analyse the transformed and untransformed disease data whose analysis was compared and gave similar results.

\section{RESULTS}

Agar infusion technique

Figure $1 \mathrm{a}$ shows the inhibitory effect of acetone plant extracts on C. lindemuthianum at 6 DAI. Allium extract completely inhibited C. lindemuthianum at all concentrations and Agapanthus extract completely inhibited C. lindemuthianum at $5.0 \mathrm{mg} / \mathrm{ml}$ over the 

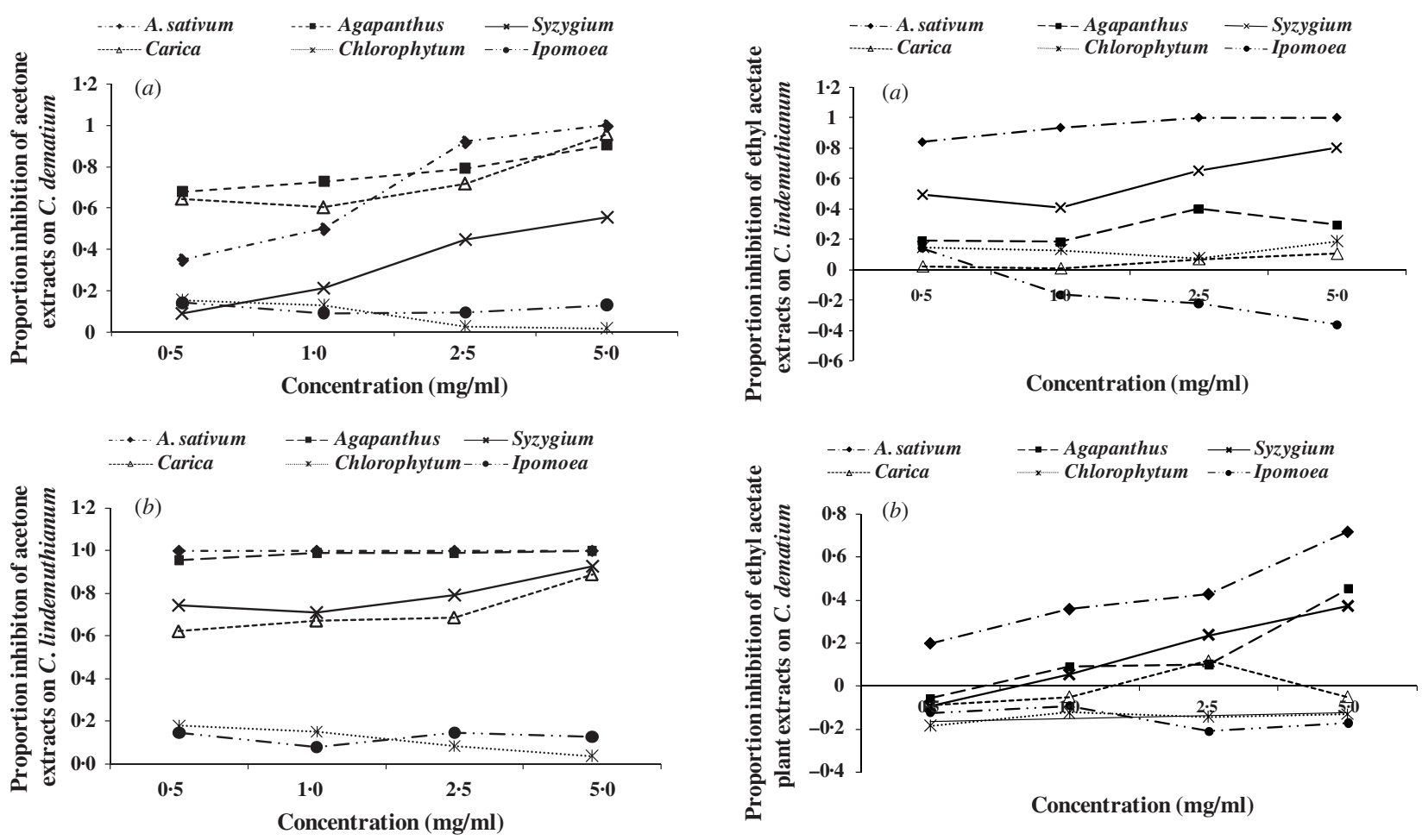

Fig. 1. The effect of acetone crude plant extracts on the colony growth of (a) C. lindemuthianum and (b) C. dematium at 6 days after inoculation.

control. The inhibition increased as the concentrations of all extracts increased, with the exception of Chlorophytum and Ipomoea leaf extracts. In fact, Chlorophytum extracts stimulated fungal growth as the concentrations increased. Allium acetone extracts completely inhibited the growth of $C$. dematium at $5.0 \mathrm{mg} / \mathrm{ml}$ only, whereas Carica and Agapanthus extracts inhibited the growth of $C$. dematium compared with the control by 96 and $90 \%$, respectively, at the highest concentration (Fig. 1b). Likewise, in C. lindemuthianum, the increase in Chlorophytum and Ipomoea extract concentrations promoted the growth of $C$. dematium.

Allium ethyl acetate extracts completely inhibited the growth of $C$. lindemuthianum at 2.5 and $5.0 \mathrm{mg} / \mathrm{ml}$ (Fig. 2a), whereas Syzygium ethyl acetate extract inhibited growth by $80 \%$ at $5.0 \mathrm{mg} / \mathrm{ml}$ compared with the control. All other ethyl acetate plant extracts (Agapanthus, Carica, Chlorophytum and Ipomoea) failed to inhibit $C$. lindemuthianum by $50 \%$ or more at any concentration. Allium ethyl acetate extract inhibited growth of C. dematium by $87 \%$, but the lower concentrations of extracts from this species inhibited growth by less than $50 \%$ compared with the control (Fig. 2b). Extracts of Ipomoea promoted the

Fig. 2. The effect of ethyl acetate crude plant extracts on the colony growth of (a) C. lindemuthianum and (b) $C$. dematium at 6 days after inoculation.

growth of $C$. lindemuthianum and $C$. dematium as concentrations increased.

The Carica water extract completely inhibited the growth of $C$. lindemuthianum at $5.0 \mathrm{mg} / \mathrm{ml}$ followed by Chlorophytum and Agapanthus extracts that inhibited the growth by 95 and $89 \%$, respectively (Fig. 3a). Agapanthus water extracts inhibited growth of $C$. dematium by $80 \%$, whereas the remainder of the extracts failed to reach $50 \%$ inhibition (Fig. 3b). Ipomoea extracts of all the concentrations, promoted growth of $C$. dematium. The Chlorophytum water extracts promoted the growth of $C$. dematium.

\section{Microtitre double-dilution method}

Table 2 shows the MIC extracted with acetone, ethyl acetate and water extracts from different plant species. All the Syzygium extracts were active against $C$. dematium and $C$. lindemuthianum. Allium extracts were also active against $C$. dematium and C. lindemuthianum; however, the water extract failed to inhibit the growth of $C$. lindemuthianum. Agapanthus acetone and ethyl acetate extracts were active against both fungi with MICs of 1.56, 3.13 and 


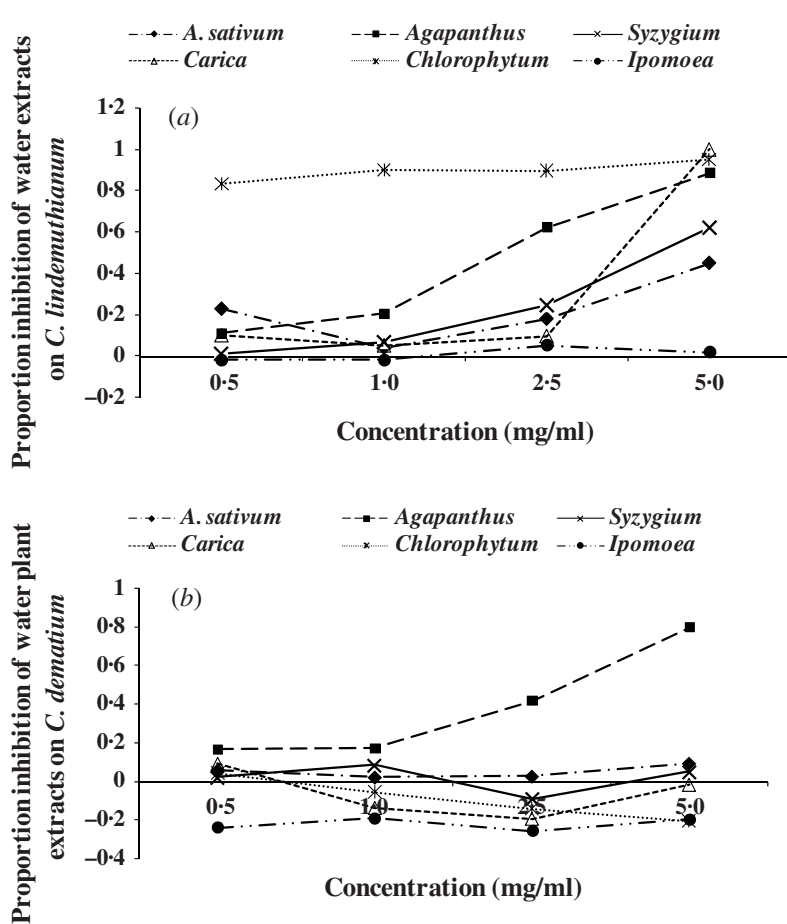

Fig. 3. The effect of water crude plant extracts on the colony growth of (a) C. lindemuthianum and (b) $C$. dematium at 6 days after inoculation.

$6.25 \mathrm{mg} / \mathrm{ml}$, respectively, but the range of concentrations of water extracts did not reveal a MIC. Carica and Chlorophytum water extracts were active against C. lindemuthianum, but their organic extracts were inactive against both C. dematium and C. lindemuthianum. All the Ipomoea extracts and DMSO were inactive against both $C$. dematium and C. lindemuthianum. Celest ${ }^{\circledR} \mathrm{XL}$ had a MIC of $0 \cdot 09 \mathrm{mg} / \mathrm{ml}$, the highest inhibitory activity when compared with all the plant extracts.

\section{In vivo antifungal test}

The plants from bean seeds treated with water extracts of Agapanthus ( 5 and $15 \mathrm{mg} / \mathrm{ml}$ ), acetone extracts from Carica $(15 \mathrm{mg} / \mathrm{ml})$ and Syzygium $(5 \mathrm{mg} / \mathrm{ml})$ extracts showed no anthracnose disease incidence (Fig. 4a). The above extracts and $5 \mathrm{mg} / \mathrm{ml}$ water extracts from Allium had low anthracnose disease incidence and compared well with the non-inoculated control and Celest $^{\circledR}$ XL. All the acetone plant extracts, $5 \mathrm{mg} / \mathrm{ml}$ Allium and Syzygium water extract-treated seeds gave bean plants that had significantly $(P \leqslant 0 \cdot 05)$ lower anthracnose disease severity than other water treatments and compared well with Celest ${ }^{\circledR} \mathrm{XL}$ and the non-inoculated control (Fig. 4b).
Water extracts from Allium, Carica and Syzygium and acetone extracts from Agapanthus, Carica and Syzygium showed no or the lowest cowpea anthracnose disease incidence (Fig. 4c) and compared well with the non-inoculated control and Celest ${ }^{\mathbb{B}} \mathrm{XL}$. All the plant extracts and the positive controls had low cowpea anthracnose disease severity and were not significantly different $(P \leqslant 0 \cdot 05)$ from each other, except for the plants from seeds treated with $(15 \mathrm{mg} / \mathrm{ml})$ Allium acetone extract and the negative controls (Fig. $4 d$ ).

\section{DISCUSSION}

Acetone and ethyl acetate extracts from Allium compared well with Celest ${ }^{\circledR} \mathrm{XL}$ by completely inhibiting $C$. lindemuthianum and $C$. dematium in the agar infusion technique. The Allium water extract inhibited the growth of $C$. dematium in the microtitre doubledilution technique. The performance of Allium water extracts on $C$. dematium is similar to the findings of Shovan et al. (2008), where Allium water extracts inhibited the growth of $C$. dematium.

Chlorophytum water extracts had higher inhibition values on $C$. lindemuthianum than acetone or ethyl acetate extracts and it can be speculated that the $C$. lindemuthianum antifungal chemical in C. comosum is only soluble in water and not in acetone or ethyl acetate. Chlorophytum water extracts failed to inhibit the growth of C. dematium, which contrasted with the findings of Raghavendra et al. (2006) where aqueous extracts of Chlorophytum boriviliam reduced the incidence of C. dematium. The difference in results could be due to differences in species of Chlorophytum used in the two studies.

Carica leaf water extracts at $5.0 \mathrm{mg} / \mathrm{ml}$ performed well and was comparable to Celest ${ }^{\mathbb{B}} \mathrm{XL}$, by completely inhibiting the growth of $C$. lindemuthianum in the agar infusion technique, but failed to inhibit the growth of $C$. dematium. The failure of Carica water extracts to inhibit the growth of $C$. dematium could be due to differences in chemical or genetic composition between the two Colletotrichum spp. used in the present study. The performance of Carica water extracts on C. lindemuthianum was superior to that of organic extracts in both in vitro techniques used in the present study and these results are in agreement with the findings of Anibijuwon \& Udeze (2009), who reported that Carica leaf water extracts gave higher inhibition against bacteria than organic extracts. 
Table 2. The MIC of selected plants extracts on Colletotrichum dematium and Colletotrichum lindemuthianum

\begin{tabular}{|c|c|c|c|c|c|c|}
\hline \multirow[b]{3}{*}{ Plant extracts } & \multicolumn{6}{|c|}{ Solvent } \\
\hline & \multicolumn{2}{|c|}{ Acetone } & \multicolumn{2}{|c|}{ Ethyl acetate } & \multicolumn{2}{|c|}{ Water } \\
\hline & $\mathrm{CL}(\mathrm{mg} / \mathrm{ml})$ & $\mathrm{CD}(\mathrm{mg} / \mathrm{ml})$ & $\mathrm{CL}(\mathrm{mg} / \mathrm{ml})$ & $\mathrm{CD}(\mathrm{mg} / \mathrm{ml})$ & $\mathrm{CL}(\mathrm{mg} / \mathrm{ml})$ & $\mathrm{CD}(\mathrm{mg} / \mathrm{ml})$ \\
\hline Allium sativum & $0 \cdot 78$ & $0 \cdot 78$ & $0 \cdot 78$ & $3 \cdot 13$ & 0 & $6 \cdot 25$ \\
\hline Agapanthus caulescens & $6 \cdot 25$ & $3 \cdot 13$ & $3 \cdot 13$ & $1 \cdot 56$ & 0 & 0 \\
\hline Syzygium cordatum & $3 \cdot 13$ & $6 \cdot 25$ & $0 \cdot 78$ & $1 \cdot 56$ & $1 \cdot 56$ & $3 \cdot 13$ \\
\hline Carica papaya & 0 & 0 & 0 & 0 & $1 \cdot 56$ & 0 \\
\hline Chlorophytum comosum & 0 & 0 & 0 & 0 & $12 \cdot 5$ & $12 \cdot 5$ \\
\hline Ipomoea batatas & 0 & 0 & 0 & 0 & 0 & 0 \\
\hline Celest ${ }^{\circledR} \mathrm{XL}$ & $0 \cdot 09$ & $0 \cdot 09$ & $0 \cdot 09$ & $0 \cdot 09$ & $0 \cdot 09$ & $0 \cdot 09$ \\
\hline DMSO & 0 & 0 & 0 & 0 & 0 & 0 \\
\hline
\end{tabular}

$\mathrm{CL}$, colletotrichum lindemuthianum; $\mathrm{CD}$, colletotrichum dematium; $\mathrm{DMSO}$, dimethyl sulphoxide.
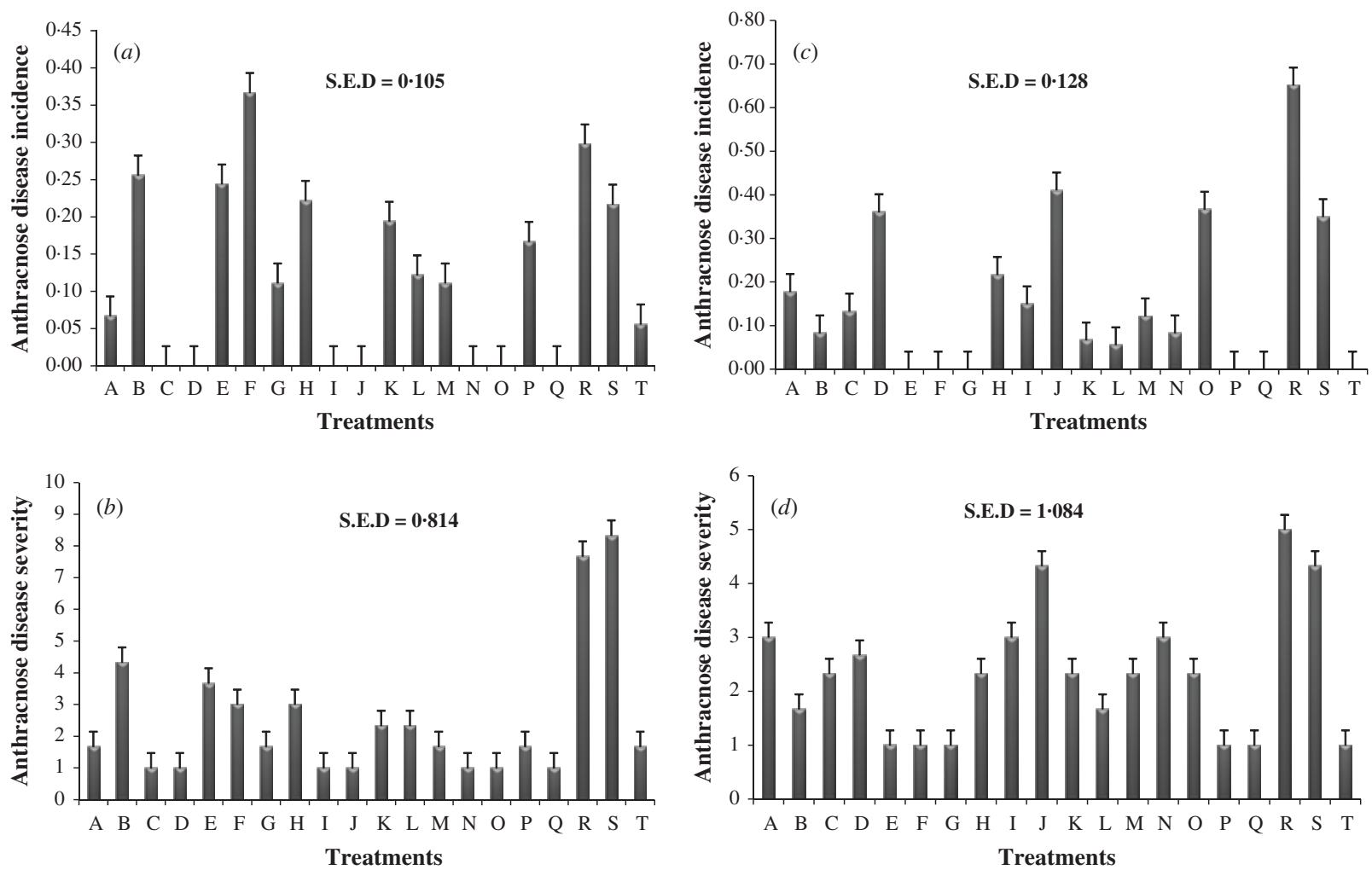

Fig. 4. (a) Proportion of bean seedlings affected with anthracnose: disease incidence. (b) Anthracnose disease severity of bean seedlings from seeds treated with plant extracts. (c) Proportion of cowpea seedlings affected with anthracnose: disease incidence. (d) Anthracnose disease severity of cowpea seedlings from seeds treated with plant extracts. Treatments A-H = water extracts and $\mathrm{I}-\mathrm{P}=$ acetone extracts $(\mathrm{A}=5 \mathrm{mg} / \mathrm{ml}$ garlic extracts; $\mathrm{B}=15 \mathrm{mg} / \mathrm{ml}$ garlic extracts; $\mathrm{C}=5 \mathrm{mg} / \mathrm{ml}$ Agapanthus extracts; $\mathrm{D}=15 \mathrm{mg} / \mathrm{ml}$ Agapanthus extracts; $\mathrm{E}=5 \mathrm{mg} / \mathrm{ml}$ Carica extracts; $\mathrm{F}=15 \mathrm{mg} / \mathrm{ml}$ Carica extracts; $\mathrm{G}=5 \mathrm{mg} /$ $\mathrm{ml}$ Syzygium extracts; $\mathrm{H}=15 \mathrm{mg} / \mathrm{ml}$ Syzygium extracts; I= $5 \mathrm{mg} / \mathrm{ml}$ garlic extracts; J=15 mg/ml garlic extracts; $\mathrm{K}=5 \mathrm{mg} / \mathrm{ml}$ Agapanthus extracts; $\mathrm{L}=15 \mathrm{mg} / \mathrm{ml}$ Agapanthus extracts; $\mathrm{M}=5 \mathrm{mg} / \mathrm{ml}$ Carica extracts; $\mathrm{N}=15 \mathrm{mg} / \mathrm{ml}$ Carica extracts; $\mathrm{O}=5 \mathrm{mg} / \mathrm{ml}$ Syzygium extracts; $\mathrm{P}=15 \mathrm{mg} / \mathrm{ml}$ Syzygium extracts). $\mathrm{Q}=$ non-inoculated control; $\mathrm{R}=$ inoculated control; $\mathrm{S}=\mathrm{DMSO}$ and $\mathrm{T}=\mathrm{Celest}^{\circledR} \mathrm{XL}$. 
However, Carica water extracts failed to maintain superiority in vivo by permitting a higher incidence and severity of bean anthracnose disease than other extracts, but was one of the best treatments in recording no incidence of cowpea anthracnose disease.

All Syzygium extracts were active against both $C$. dematium and $C$. lindemuthianum in the microtitre double-dilution experiment and the in vivo experiment where they had the lowest cowpea and bean anthracnose disease incidence and severity.

Generally, there was an increase in inhibition of fungal colony growth by the other plant extracts as concentrations increased and this could have been due to the increased availability of the antifungal chemicals in the media. Cao \& van Bruggen (2001) reported the increase in inhibition of the growth of Phytophthora infestans in media when A. sativum extract concentrations were increased. However, the growth of Colletotrichum increased with concentration of Ipomoea leaf extracts and it can be speculated that these leaves have some constituents that are required for growth of Colletotrichum. Morris \& Ward (1992) found that some plant chemical compounds such as the isoflavone daidzein stimulated the germination of zoospores of Phytophthora sojae (Kaufman and Gerdemann) and Pythium irregulare (Buisman) on Glycine max (L.) Merrill soybean (G. max (L.) Merrill).

Acetone plant extracts showed the highest inhibitory activity among the solvent extracts in vitro and also gave good results in vivo. Masoko et al. (2005) also found that acetone extracts were superior to other extraction solvents such as hexane, dichloromethane and methanol. The sequential extracting method could have a contribution towards the poor performance of ethyl acetate extracts compared with acetone extracts because most of the organic soluble chemicals in plants had already be extracted in the acetone and little remained in the residues. The water extracts gave poor results in vitro, but performed well in vivo because lower concentrations $(0.5-5 \mathrm{mg} / \mathrm{ml})$ were used in vitro and higher concentration $(5-15 \mathrm{mg} / \mathrm{ml})$ in vivo. The water extract results could be due to the solubility of compounds in water as speculated by Masoko et al. (2005), who stated that water fails to extract non-polar active compounds in plant materials. This explains a need for higher plant water extracts concentration to achieve fungal toxic level.
The present study has contributed an additional list of plants that can potentially be used by smallholder farmers to control anthracnose diseases of common bean and cowpea. All the plant extracts except Carica water extracts were effective in reducing anthracnose disease severity. The anthracnose disease incidences in some seedlings from extracts and Celest ${ }^{\circledR} \mathrm{XL}$ treated seeds could be due to the deep-seated infections that escaped treatment. Extracts from the plant species used in the present study can be adopted easily as seed treatments by farmers because the plants from which the extracts were made can be accessed easily around their homesteads and the seed treatment process is simple to follow. The smallholder farmers can therefore use $A$. sativum, $A$. caulescens and $S$. cordatum extracts to treat their common bean and cowpea seeds by soaking to avoid the yield losses due to anthracnose disease. The use of the above-stated plant extracts by farmers can also result in the reduction of pesticiderelated illnesses suffered by farmers after using the synthetic fungicides (Ngowi et al. 2007).

There is, however, a need to investigate further the performance of water and acetone $A$. sativum, A. caulescens, C. papaya and S. cordatum extracts in vivo as both seed treatments and foliar fungicides to control anthracnose disease of cowpea and common bean in the same way that $A$. sativum and $C$. papaya leaf extracts have been used as foliar fungicides to control pests and blight in Uganda (Mwine et al. 2011).

We thank the Forum for Agricultural Research in Africa (FARA) and the African Development Bank for student bursary support. The National Research Foundation (NRF) for financial assistance and Syngenta SA (Pty) Ltd for providing Celest $^{\circledR} \mathrm{XL}$.

\section{REFERENCES}

Adebanjo, A. \& Bankole, S. A. (2004). Evaluation of some fungi and bacteria for biocontrol of anthracnose disease of cowpea. Journal of Basic Microbiology 44, 3-9.

Akinbode, O. A. \& IкотUN, T. (2008). Evaluation of some bioagents and botanicals in in vitro control of Colletotrichum destructivum. African Journal of Biotechnology 7, 868-872.

Allen, D. J. (1983). The Pathology of Tropical Food Legumes: Disease Resistance in Crop Improvement. Chichester, UK: John Wiley and Sons.

Amadioha, A.C. (2003). Evaluation of some plant leaf extracts against Colletotrichum lindemuthianum in cowpea. Acta Phytopathologica et Entomologica Hungarica 38, 259-265. 
ANiBIJUWON, I. I. \& UdEZE, A. O. (2009). Antimicrobial activity of Carica papaya (pawpaw leaf) on some pathogenic organisms of clinical origin from South-Western Nigeria. Ethnobotanical Leaflets 13, 850-864.

Aveling, T.A.S., Govender, V., Kandolo, D.S. \& KritZINGeR, Q. (2012). The effects of treatments with selected pesticides on viability and vigour of maize (Zea mays) seeds and seedling emergence in the presence of Fusarium graminearum. Journal of Agricultural Science, Cambridge, published online doi:10.1017/ S0021859612000457.

Beaver, J.S., Rosas, J. C., Myers, J., Acosta, J., Kelly, J. D., Nchimbi-Msolla, S., Misangu, R., Bokosi, J., Temple, S., Arnaud-Santana, E. \& Coyne, D. P. (2003). Contributions of the bean/cowpea CRSP to the management of bean diseases. Field Crops Research 82, 87-102.

Cano, J., Guarro, J. \& Gené, J. (2004). Molecular and morphological identification of Colletotrichum species of clinical interest. Journal of Clinical Microbiology 42, 2450-2454.

CaO, K. Q. \& Van Bruggen, A. H.C. (2001). Inhibitory efficacy of several plant extracts and plant products on Phytophthora infestans. Journal of the Agricultural University of Hebei 2, 90-96.

Centro Internacional De Agricultura Tropical (CIAT) (1987). Standard System for the Evaluation of Bean Germplasm (Eds A. Van Schoonhoven \& M. A. Pastor-Corrales). Cali, Colombia: CIAT.

Chowdhury, M. N. A., Rahim, M. A., Khalequzzaman, K. M., Humauan, M. R. \& Alam, M.M. (2007). Effect of plant extracts and time of application on incidence of anthracnose, yield and quality of mango. International Journal of Sustainable Crop Production 2, 59-68.

Falandysz, J. (2000). Residues of hexachlorobenzene in Baltic fish and estimation of daily intake of this compound and pentachlorobenzene with fish and fishery products in Poland. Polish Journal of Environmental Studies 9, 377383.

Fawole, O. A., Finnie, J.F. \& Van Staden, J. (2009). Antimicrobial activity and mutagenic effects of twelve traditional medicinal plants used to treat ailments related to the gastro-intestinal tract in South Africa. South African Journal of Botany 75, 356-362.

JenG, T. L., Shih, Y. J., Lal, C.C., Wu, M.T. \& Sung, J.M. (2009). Anti-oxidative characterisation of $\mathrm{NaN}_{3}-$ induced common bean mutants. Food Chemistry 119, 1006-1011.

Kritzinger, Q., Lall, N. \& Aveling, T. A.S. (2005). Antimicrobial activity of cowpea (Vigna unguiculata) leaf extracts. South African Journal of Botany 71, 45-48.

Masoko, P., Picard, J. \& Eloff, J. N. (2005). Antifungal activities of six South African Terminalia species (Combretaceae). Journal of Ethnopharmacology 99, 301308.

Mathur, S. B. \& Kongsdal, O. (2003). Common Laboratory Seed Health Testing Methods for Detecting Fungi. 1st edn. Bassersdorf, $\mathrm{CH}$, Switzerland: International Seed Testing Association.

MdeE, L. K., Masoko, P. \& Ellof, J. N. (2009). The activity of extracts of seven common invasive plant species on fungal phytopathogens. South African Journal of Botany 75, 375379.

Mendiratta, D. K., Thamke, D., Shukla, A. K. \& Narang, P. (2005). Keratitis due to Colletotrichum dematium - a case study report. Indian Journal of Medical Microbiology 23, 56-58.

MORRIS, P. F. \& WARD, E. W. B. (1992). Chemoattraction of zoospores of the soybean pathogen Phytophthora sojae by isoflavones. Physiological and Molecular Plant Pathology 40, 17-22.

Msuku, W. A. B., SaKa, V. W. \& Munthali, D. C. (2000). Major Diseases and Insect Pests of Beans (Phaseolus vulgaris) in Malawi: Problems and their Control. Study Guide. Lilongwe, Malawi: Bunda College of Agriculture, University of Malawi.

Mwine, J., Van Damme, P., Kamoga, G., Kudamba, Nasuuna, M. \& JUmBA, F. (2011). Ethnobotanical survey of pesticidal plants used in South Uganda: Case study of Masaka district. Journal of Medicinal Plants Research 5, 11551163.

Nduagu, C., Ekefan, E. J. \& Nkwankiti, A. O. (2008). Effect of some crude plant extracts on growth of Colletotrichum capsici (Synd) Butler \& Bisby, causal agent of pepper anthracnose. Journal of Applied Biosciences 6, 184-190.

$\mathrm{NG}$, T.B. (2004). Antifungal proteins and peptides of leguminous and non-leguminous origins. Peptides 25, 1215-1222.

Ngowı, A. V.F., Mbise, T. J., IJANI, A.S. M., London, L. \& AJAYI, O.C. (2007). Smallholder vegetable farmers in Northern Tanzania: pesticides use practices, perceptions, cost and health effects. Crop Protection 26, 1617-1624.

Pastor-Corrales, M. A. \& Tu, J. C. (1989). Anthracnose. In Bean Production Problems in the Tropics (Eds H.F. Schwartz \& M. A. Pastor-Corrales), pp. 77-104. Cali, Colombia: CIAT.

Pretorius, J. C., Zietsman, P.C. \& Eksteen, D. (2002). Fungitoxic properties of selected South African plant species against plant pathogens of economic importance in agriculture. Annals of Applied Biology 141, 117-124.

Raghavendra, V. B., LoKesh, S., Girisha, S. T., Govindappa, M. \& Prakash, H.S. (2006). Antifungal activity of aqueous extract of safed musli against seed mycoflora of some crop species. American-Eurasian Journal of Agricultural and Environmental Sciences 1, 86-90.

Shovan, L. R., Bhuiran, M. K. A., Begum, J. A. \& Pervez, Z. (2008). In vitro control of Colletotrichum dematium causing anthracnose of soybean by fungicides, plant extracts and Trichoderma harzianum. International Journal of Sustainable Crop Production 3, 10-17.

Sibanda, T., Dobson, H. M., Cooper, J. F., Manyangarirwa, W. \& ChiмmвA, W. (2000). Pest management challenges for smallholder vegetable farmers in Zimbabwe. Crop Protection 19, 807-815.

Taiga, A., Suleiman, M. N., Sule, W. \& Olufolajl, D. B. (2008). Comparative in vitro inhibitory effects of cold extracts of some fungicidal plants on Fusarium oxysporium Mycelium. African Journal of Biotechnology 7, 33063308. 
Tegegne, G., Pretorius, J. C. \& Swart, W. J. (2008). Antifungal properties of Agapanthus africanus L. extracts against plant pathogens. Crop Protection 27, 1052-1060.

Tian, F., Zhu, J., Sun, M., Jiang, J., Wang, S. \& Zhang, W. (2007). Induction and mechanism of cucumber resistance to anthracnose induced by Pieris rapae extract. Frontiers of Agriculture in China 2, 137-140.
Vsn International (VSNi) (2008). GenStat Discovery, edition 3. Software (now ed. 4) available online at http://www. vsni.co.uk (verified 3 May 2012).

Wong, J. H., ZhanG, X. Q., WanG, H. X. \& NG, T. B. (2006). A mitogenic defensin from white cloud beans (Phaseolus vulgaris). Peptides 27, 2075-2081. 